О.О.Полисаєв,

аспірант кафедри філософії ДВНЗ «ПХДПУ імені Григорія Сковороди»

\title{
ПОЛТТИЧНЕ ЛІДЕРСТВО ЯК КОРЕЛЯТ ПОСТУПУ СУЧАСНОГО СУСПІЛЬСТВА
}

Проблема теоретичного дослідження політичного лідерства $\epsilon$ однією з найбільш дискусійних - адже сучасні процеси глобалізації та динаміка соціальних трансформацій зумовлюють ії особливе значення. Впродовж останнього часу діапазон наукових розвідок, присвячених названій проблемі, значно розширився - від досліджень психологів, правників та нейрофізіологів до теоретичних узагальнень філософів. Завдяки цьому маємо низку відкриттів у вивченні процесів соціалізації та групової самоорганізації, які дозволяють визначити певні перспективні спрямування в дослідженні феномену лідерства.

Водночас закономірні тенденції становлення сучасного суспільства змушують нас віднаходити інноваційні підходи щодо вказаного феномену, який надав принципово нової якості науковому дискурсу та інформаційно-публіцистичним інтерпретаціям. Зазначимо, що уявлення широкого загалу про сутнісні характеристики політичного лідерства формувались під визначальним впливом уявлень про унікальність даного соціального феномену, здатного змінити перебіг історичного процесу та забезпечити власному етносу чільне місце в суспільному поступі. Разом з тим впродовж останнього часу все більшого значення почали набувати підходи функціонального змісту, за якими громадсько-політичного діяча пропонують розглядати як найнятого для публічної діяльності менеджера. Це неминуче звужує тлумачення сутності лідерства, зводячи його до розпорядницького рівня. Приклад - деякі сучасні політики, демонструючи певні чиновницькі здатності, виявляють повну безпорадність у вирішенні стратегічних проблем.

Досліджуючи принципи володарювання, механізми узурпації влади, ми акцентуємо увагу на аналізі ключового поняття зазначеного кола проблем, а саме - політичного лідерства, яке форматується відповідно до очікувань суспільства. Будь-яка спільнота, передусім заради власних інтересів, має виробити механізми контролю за діяльністю владних інституцій та механізми запобігання будь-яким 
спробам посадових зловживань.

Над проблемою політичного лідерства працювали такі видатні мислителі давнини, як: Сократ, Платон, Аристотель, Геракліт, Цицерон. Саме вони стали основоположниками концепцій лідерства в античності. В епоху Відродження та Нового часу це - Н.Макіавеллі, що визначив деякі основні характеристики діяльності тогочасних лідерів, Т.Гоббс, що розробив концепцію абсолютного суверена. Різні аспекти політичного лідерства, що мають відгук в сучасності, розробили Ф.Ніцше, Ж.Блондель, М.Бердяєв, М.Вебер, Г.Гегель, Т.Карлейль, А.Шопенгауер та ін. Вони зуміли віднайти ключові аспекти розвитку політичного лідерства, визначити основні ознаки даного феномену, підкреслюючи людську природу в контексті жаги до влади. Серед вітчизняних науковців значний вклад у висвітлення розглядуваної проблеми здійснили С. Кузнецова, А.Пахарев, Г.Почепцов, В.Ребкало, В.Рихлик та ін.

Розглянемо динаміку трансформацій основних позицій політичних лідерів у рамках сучасного громадянського суспільства, тобто зосередимо увагу на найбільш дієвому функціонуванні політичного діяча 3 лідерськими установками. Достатньо значного поширення набрала концепція, згідно 3 якою політичного очільника сучасності суспільство наймає, проголосувавши за нього. В цілому його роль можна трактувати як розпорядника-виконавця, діяльність якого чітко визначена завчасно електоральними очікуваннями та настроями. Основна мета такого типу лідера - задовольнити очікування народу, які були проголошені в ході виборчої кампанії та апеляцій до суспільства шляхом презентації «найбільш досконалої програми». Сучасна людина сприймає це як належне. Адже назване і $є$ власне роботою сучасного політика нового типу (варто наголосити й на тому, що таким чином його наймають на роботу). Як менеджер політик такого типу виконує конкретні функції, які, однак, відрізняють його від апаратного чиновника лише способом приходу у владу - політика не призначають на посаду, а обирають шляхом народного голосування. Вважаємо, що саме це радикально виводить проблему за рамки класичного уявлення про лідерство, адже на рівні широкого загалу відбувається переворот у трактуванні самого лідера, який власне подається суспільству через певні медійні проекти найнятими політтехнологами.

Через низку суспільно-політичних трансформацій лідера перестають розглядати в суспільстві як індивідуальність та харизматичну 
особистість, яка ставить за мету змінити світ в інтересах широкого загалу і $\epsilon$ виразником глибинних народних прагнень. В умовах інформаційного суспільства лідерство починає сприйматись як командна гра, в межах якої кожен учасник виконує вкрай важливу i необхідну роботу, а лідер, як капітан команди, є просто хорошим виконавцем, що отримав свою роль завдяки тренеру та обставинам, нерідко випадковим для нього. На наш погляд, варто зробити порівняльний аналіз політичного лідерства у класичній інтерпретації та його постмодерністські тлумачення. Для цього звернемось до розуміння проблеми типології лідерства в сучасній політології, яка застосовує такі критерії: функції і роль лідера в суспільстві, стиль та методи його діяльності, ціннісні орієнтації, характер участі в організації політичної влади, масштаб і рівень його впливу на соціум.

Відомий західний політолог М.Херманн, застосовуючи критеpiї теоретичного дослідження функцій і ролі політичного лідера в системі владних відносин, запропонував достатньо обгрунтовану класифікацію політичних лідерів, поділивши їх таким чином:

А) лідер «комівояжер» - сенс своєї діяльності вбачає у втіленні й задоволенні певного набору потреб та інтересів своїх прихильників та послідовників;

Б) лідер «пожежник» - здатен швидко реагувати на умови нестандартної соціальної ситуації, тобто намагається діяти тут і зараз, протидіючи негативним умовам або загрозам існування власної спільноти;

В) лідер - «маріонетка» - перебуває під впливом групи наближених осіб, якій він беззастережно довіряє. Підкреслимо, що у вказаній групі є чимала частка прагматиків, які не $\epsilon$ його особистими послідовниками, їхній інтерес зосереджений скоріше на власних цінностях та бажаннях i, як показує практика, названі прагматики вмотивовані аж ніяк не альтруїстичними настроями щодо суспільства $[1,92]$.

На нашу думку, з трьох типів сучасного політичного лідера, визначених М.Херманном, варто звернути особливу увагу на останній, третій тип, а саме - на «лідера-маріонетку». Зрозуміло, що в реальному житті вкрай важко виділити названий тип у чистому вигляді. Як правило, він містить у собі елементи двох інших, однак в рамках інформаційного суспільства набрав значного поширення передусім через дію соціальних чинників. Адже сучасні управлінські моделі неодмінно передбачають теоретичне осмислення та опрацювання рішень, що приймаються політиками в різноманітних сферах - 
військовій, економічній, освітній, науково-технічній та ін. Зрозуміло, що сучасний політичний діяч зобов'язаний формувати фахову команду однодумців, нерідко талановитих особистостей. Сам він лише представляє інтереси елітарного угруповання, яке спрямовує напрями соціальних трансформацій.

Під час розгляду вищевказаного кола проблем виникає закономірне питання: наскільки виправданою є концептуалізація третього типу лідерства як визначальна? Справді, процеси глобалізації по суті своїй передбачають різноманітні фази соціальних перетворень, в межах яких стає нагальною соціальною потребою поява інших функціоналів лідерства або навіть їх симбіозу. На наш погляд, визначальним фактором тут виступають соціальна ситуація та рівень згуртованості пасіонарних суспільних верств, корелятом яких і $є$ соціальний запит на певний лідерський алгоритм. Водночас зазначимо, що масштаб діяльності політичного лідера визначається передусім його здатністю подолати корпоративну обмеженість власної верстви та здатністю набути рис загальнонаціонального лідера. Блискучим підтвердженням такої трансформації є Богдан Хмельницький, який iз оборонця «козацьких вольностей» на початку повстання, за дуже короткий час перетворився на визнаного лідера української нації $[2,127]$. На жаль, українська історія дає нам чимало прикладів зворотного характеру - коли політичні діячі, номіновані в масовій свідомості як лідери, так і не змогли піднестись вище містечкового рівня власних світоглядних вимірів.

Для того, щоб більш досконало проаналізувати феномен політичного лідерства, варто звернутись до аналізу поведінкових моделей відомих американських діячів, запропонованих професором Дж. Фарбером. Це такі моделі:

- активно-позитивна, найбільш ефективна, адже лідер, якому вона притаманна, вирізняється продуктивною працею, раціональним усвідомленням власних завдань, рефлексивним співвідношенням особистих здібностей та можливостей;

- активно-негативна, зорієнтована на задоволення власних амбіцій шляхом кар'єрного зростання, яке вмотивоване егоцентричними властивостями людини;

- пасивно-позитивна - модель реалізації обов'язків - спрямована на збереження лідером особистих ціннісних орієнтирів, уявлень, а також кола прихильників, які змушують лідера приймати політичні рішення в межах незмінних традицій; 
- пасивно-негативна, що передбачає мінімальне виконання лідером своїх обов'язків у межах існуючої системи професійних відносин, однак для такого лідера характерне - або переадресація власних обов'язків, або імпульсивне прийняття необдуманих рішень [3, 395].

Як бачимо, психологічний контент політичного лідерства $\epsilon$ вкрай важливим чинником діяльнісних установок особистості, яка претендує на провідну соціальну роль. Водночас слід зазначити, що психологічна складова, як правило, виступає лише фоном на тлі соціальних очікувань та настроїв широкого загалу.

Розглядаючи апологізацію політичного лідерства та стилів психологічної поведінки в напрямі реалізації обов'язків, варто звернути увагу на концепцію Р.Стогділла, який зазначає, що «в основі своїй лідерство - це продукт (соціальної. - Авт.) ситуації» [3, 395]. У різноманітних обставинах функціонування соціуму в середовищі пасіонарних прошарків виокремлюються окремі особистості, які хоча б частково переважають інших певним набором здатностей, однак саме вони і $є$ найбільш прийнятними для конкретних соціальних обставин, зумовлених конкретними факторами всього попереднього соціального досвіду спільноти і є домінантними в даному соціумі. Причому поведінкові моделі політичних лідерів у попередні історичні часи визначались міфологізованими архетипами та достатньо жорстко регламентували діяльність публічних осіб, немовби підганяючи їх під наперед визначені алгоритми. Особа, в якої найкраще були розвинені саме ці властивості, здобувала шанс посісти керівну роль у соціумі, а за умови підтримки іiі активними соціальними прошарками та найбільш освіченими для свого часу верствами стати харизматичним політиком, реальна біографія якого та легендарні перекази про його діяння просто вражають своєю несумісністю. Адже архетип вождя-родоначальника передбачає тлумачення його зверхності в усіх без винятку сферах людської діяльності - політичній, військовій, судовій, організаційній та ін. I якщо навіть такий лідер програє, відповідальність за невдачу покладається на незалежні обставини або ж на безталанних виконавців, які не зуміли правильно реалізувати задум свого очільника.

Отже, від інтуїції та інтелектуального контенту лідера безпосередньо залежить перебіг соціально-політичних процесів, однак можливості впливу на них детерміновані конкретно-історичними чинниками, в межах яких сформовано і політичну спільноту, і власне самого політичного діяча. За Стогділлом, це - функція обста- 
вин, а людина, яка може бути лідером у конкретній ситуації, за інших життєвих обставин просто не зможе реалізувати свої лідерські задатки повною мірою. Особливістю такої точки зору є те, що лідерські якості тлумачаться як доволі відносні, хоча прихильники ситуативної концепції все ж таки визнають необхідність компетентності, цілеспрямованості, впевненості у своїх силах, готовності взяти на себе відповідальність за розв'язання того чи іншого завдання [3, 396]. На нашу думку, слабкість ситуативної концепції полягає в недооцінюванні особистісної активності людини, яка, маючи лідерський потенціал, все ж таки здатна проявити себе не лише у сфері публічної політики, але і в інших спрямуваннях скажімо, духовно-інтелектуальному чи військовому.

У даному контексті важливою є думка американського дослідника Е. Хартлі, який запропонував чотири «соціальні моделі», що дозволяють дати особливу інтерпретацію того, чому ж все таки деякі люди стають лідерами, а не лише особливі обставини визначають саме їх висування: 1) якщо людина стала лідером в одній ситуації, то ï шанси зайняти відповідну позицію за інших обставин підвищуються; 2) якщо особистість проявила себе як лідер, то вона неодмінно набула власного авторитету, який може посприяти призначенню іiі на керівну посаду і цим самим закріпити їі лідерство формально; 3) якщо сприйняття групи стереотипне, то, якщо людина стала лідером в одній ситуації, група сприйматиме ії в такій же соціальній ролі і за інших обставин; 4) лідером, за Е.Хартлі, стає той, хто до цього найбільше прагнув $[3,396]$, адже прагнути означає вірити у власні можливості, а це, своєю чергою, - потужна мотивація, здатна стати рушійною силою діяльності особистості.

На нашу думку, сучасне теоретичне розуміння становлення лідерства найбільш повно представлене в системній теорії лідерства, згідно з якою лідерство розглядається як процес організації міжособистих відносин в групі, а лідер - як суб'єкт управління цим процесом. За такого підходу лідерство інтерпретується як функція групи і вивчати його варто з позиції цілей та завдань групи, хоча й психологічна структура особистості лідера при цьому не має бути поза увагою дослідника. Щодо політичного лідерства необхідно зауважити, що підхід системної теорії становлення лідерства тут також $є$ продуктивним, просто в даному випадку політичний лідер уособлює інтереси вже не групи людей, а цілого громадянського суспільства і є його функцією. Кожен голос, який віддається виборцями 
за політичного лідера, розрахований на задоволення електоральних інтересів. Іншими словами, апеляція лідера до інтересів народу, а також віра людей можуть привести політика до влади, проте політик тільки тоді стане справжнім лідером, коли почне виконувати власні передвиборчі обіцянки, в протилежному випадку кредит політичної довіри впаде, як і його репутація. Політичне лідерство, як і будь-який інший вид володарювання, має свій початок та кінець. На нашу думку, лідерство - це також ресурс, який підживлюється народною довірою. Щоправда, існує ще один вид володарювання, який може існувати після вичерпання ресурсу довіри до керманича власним народом і має назву тиранії. Тиранія як прояв політичного лідерства була добре проаналізована значною кількістю як мислителів минулих епох, так і сучасними науковцями. Їй присвячено багато теорій, але всі вони дійшли спільного висновку - відсутність підтримки широкого загалу компенсується періодичними підкупами якоїсь його частини та неймовірно жорстокими розправами з незгідними. Однак цілі країни позбувались деспотів революційними заходами та, на жаль, масовими втратами людських життів. На нашу думку, кожна тиранія як процес володарювання не обійшлась без важливої в даному контексті «волі до влади», іншими словами - «жаги до правління» чи то амбітного бажання підкоряти та розпоряджатись. Термін «воля до влади» запропонував у своїх працях Ф.Ніцше, вкладаючи в нього максимальну вмотивованість до володарювання. Воля до влади - це сліпий, інстинктивний, несвідомий рух, потужний імпульс, який керує світом $[4,174]$. У своїх наукових напрацюваннях філософ поділяє всі види волі на такі напрями:

1. Воля до життя. Це поняття він успадкував у свого талановитого попередника А.Шопенгауера. Цей тип волі уособлює інстинкт самозбереження та невід'ємне бажання людини жити [5, 267].

2. Воля внутрішня - вираження стійкості думки, характеру людини, незламного духу та здатністю мати власні переконання та цілі.

3. Несвідома воля. Проаналізувавши іiі, можна стверджувати, що ця ідея є співзвучною ідеї психоаналізу 3.Фрейда, адже тут вона охоплює безсвідомі пристрасті людини, афекти, інстинкти, які керують нею $[6,187]$. Ніцше підкреслює, що люди далеко не завжди $є$ раціональними істотами, адже не здатні керувати собою цілковито.

4. Воля до влади спроможна реалізуватись у кожної людини більшою чи меншою мірою. Ця властивість, на думку мислителя, присутня в кожній живій істоті, всі бажають підкорювати собі інших 
і таким чином ставати вільними від впливу інших $[4,193]$. Влада це не те, чим можна користуватись, а те, що насправді наповнює всіх людей. Вона і є головним критерієм всіх дій людини. Це універсальний принцип, діяльність якого ми помічаємо практично на кожній сходинці існування людства. Мислитель зазначає, що не «щастя», а саме влада $є$ головною причиною, метою боротьби людини 3 життєвими негараздами. Саме усвідомлення людиною волі до влади і є основною ознакою щастя.

Ще один компонент філософії Ніцше, вартий уваги саме в контексті дослідження політичного лідерства, - теорія про так звану «надлюдину», найбільш повно викладена у роботі «Так говорив Заратустра». Філософ змальовує «надлюдину» як персону володаря не просто власної долі, а й долі інших людей. Даний феномен трактується, як носій зовсім нових цінностей, норм, моральних настанов та позицій. Надлюдина здатна і повинна бути позбавленою загальноприйнятих норм моралі, милосердя, більше того, повинна мати свій, особистий погляд на світ, корельований із абсолютно вільним вибором власних поведінкових моделей. На думку мислителя, така особистість повинна бути позбавлена совісті, адже совість - це механізм маніпуляції, управління, невидимий цар, спроможний керувати внутрішнім життям кожної людини; у неї немає терміну придатності. Надлюдина здатна не зважати на почуття інших, не звертати увагу на те, що хтось вважає іiі поведінку аморальною чи девіантною.

Основні риси «надлюдини» - це: духовна творчість, повна концентрація волі до влади, індивідуалізм (повне неприйняття норм суспільства, правил спільноти) [4, 207]. Щоб бути «надлюдиною», каже Ніцше, потрібно бути неординарною (яскравою) особистістю, вирізнятись 3-поміж інших, постійно самовдосконалюватись i, що не менш важливо, додержуватись оптимістичної життєстверджувальної позиції. Варто зауважити, що сам науковець вказує на факт неіснування надлюдини, таким чином мимохідь пророкуючи появу іï щонайменше через два століття. На думку Ніцше, сучасне суспільство неготове до появи надлюдини, не здатне ії виростити. Надлюдина протиставляє себе добрим людям (зокрема - християнам), як бездумним, не здатним до творчості, зате схильним до постійної брехні та лицемірства $[4,213]$. Це нібито нійвищий біологічний тип, який співвідноситься із сучасною людиною, так само як iз нинішніми людьми співвідноситься мавпа. 3'явившись, він стане 
абсолютно новим типом (видом) людини 3 неймовірною ознакою духовної величі.

Отже, екзистенція лідерства, а саме - його політичний формат, продовжує лишатись у центрі уваги сучасних дослідників, як і століття тому. Лідерство існує в усіх вимірах часу, більше того, воно здатне змінювати обличчя цивілізацій, прискорювати їх позитивний розвиток або своїми діями призводити до регресу. Політик - не обов'язково лідер, а лідерство - не завжди політика. Існування політичного володарювання зумовлене значною кількістю факторів, але центральною постаттю завжди виступатиме особа, наділена владою. Політичне лідерство можливе як у форматі ситуативного підходу, так і у форматі індивідуального прояву потужних інтелектуальних даних людини. Лідерство може існувати також у вигляді звичайного призначення на посаду, щоправда в даному випадку можливий прояв лідерства під назвою «лідерамаріонетки», адже особа просто виконує побажання прибічників або чиновників вищого рівня управлінського апарату. Багато вчених збагатили філософію теоріями саме політичного лідерства, називаючи власне лідера «надлюдиною» (за Ніцше), так і «пожежником» (за М.Херманном) у контексті боротьби 3 державними кризами. Політичний лідер - не просто наставник, вожак чи керівник, це, насамперед, свідома, відповідальна людина, зацікавлена в добробуті співгромадян. Проте і в наш час політичні лідери дозволяють собі не виправдовувати сподівань народу, який вже так давно прагне кращих змін. Політичний лідер у будь-якому суспільстві покликаний виконувати функції гуманістичного спрямування, а саме: об'єднувати суспільство навколо спільних цілей; створювати злагоду, консенсус, взаєморозуміння в соціумі.

Проблема політичного лідерства складна, багатогранна й багатовимірна. Тільки застосування комплексу різних методів дослідження та застосування міждисциплінарного підходу дасть змогу охопити основні грані даного феномену. Присутність людини у світі, ефективність використання нею власних часових рамок, відведених життям, і характеризують особистість 3 лідерськими якостями, адже саме від неї залежить, яким персонажем вона увійде в історію людства - позитивним чи негативним. 


\section{ЛІТЕРАТУРА}

1. Херманн $M$. Стили лидерства в формировании внешней политики. - М., 1991. - $368 \mathrm{c}$.

2. Грушевський М. Історія України-Руси. - К., 1991. - 394 с.

3. Політологія: Навчально-методичний комплекс. - К., 2004. - 697 с.

4. Нищше Ф. Так говорил Заратустра. - М., 2014. - 248 с.

5. Шопенгауэр А. Афоризмы житейской мудрости. - М., 2015. - 304 с.

6. Фрейд 3. Введение в психоанализ. - М., 1991. - 544 с.

Полисаєв О.О. Політичне лідерство як корелят поступу сучасного суспільства.

У статті досліджуються концептуальні підходи до проблеми політичного лідерства видатними мислителями минулого та їх вплив на сучасні розвідки зазначеного феномену. Піддано аналізу особливості становлення феномену лідерства в інформаційному суспільстві як чинника поступального розвитку людства.

Ключові слова: політичне лідерство, громадянське суспільство, пасіонарні верстви, соціальна ситуація, суспільний поступ, інформаційне суспільство.

Полисаев А.А. Политическое лидерство как коррелят развития информачионного общества.

В статье рассмотрены концептуальные подходы к проблеме политического лидерства выдающимися мыслителями прошлого и их влияние на современные исследования указанного феномена. Подвергнуты анализу особенности становления феномена лидерства в информационном обществе как фактора поступательного развития человечества.

Ключевые слова: политическое лидерство, гражданское общество, пассионарные слои, социальная ситуация, общественный прогресс, информационное общество.

Polysaev A. Political leadership as a correlate of the development of the informational society.

The article examines conceptual approaches to the problem of political leadership of outstanding philosophers of the past and their impact on modern research of this phenomenon. The peculiarities of the formation of the phenomenon of leadership in the information society are analyzed, as a factor of progressive development of mankind.

Key words: political leadership, civil society, passionarity layers, social situation, social progress, the informational society. 